\title{
STUDIES ON SOME PARASITES AND BIOCHEMICAL PARAMETERS ON OSTRICH IN EGYPT
}

\author{
Entessar, A. Arafa*; Azza, M. Kamal** and Salwa Awadalla* \\ * Department of Avian Disease, ** Department of Biochemistry, \\ Animal Health Research Institute, Dokki
}

\begin{abstract}
A total number of 75 Ostrich of various breads, sexes and ages were used. The study revealed that $25 \%$ among examined Ostrich infested with Ascaridia, $17.3 \%$ infested with Libostrngyloides, $13.3 \%$ with Cryptosporidium, $8 \%$ with Blantidium spp., $14.6 \%$ Giardia spp., 9.3 $\%$ Trichomonas spp. and $12 \%$ Coccidia spp. Also, the biochemical changes in serum show a significant decrease in protein, albumin, globulin, glucose and calcium and show a slightly decrease in cholesterol and non significante change in sodium and phosphorus.
\end{abstract}

\section{INTRODUCTION}

Today's Ostriches are raised in large numbers as farm animals in order to be slaughtered for their meat and skin and the veterinary approach should be bassed on flock medicine (Perelman, 1999).

Diagnostic work in Ostrich farming should be based on a good clinical history and clinical examination, a good postmortem examination and the use of laboratory work, which are indispensable for a rapid and accurate diagnosis to minimum economic change (Deaming, 1999).

Investigation of Ostrich with some parasites may induce changes in the chemical content of plasma or serum, when these changes are accurately measured and comprehensively evaluated,it is possible to determine specific organopathes or homeostatic imbalances (Van Heerden et al., 1985 ; Levy et al., 1989 ; Okotieboth et al., 1992 ; Brown and Jones, 1996 ; Fudge, 1996 ; Olowookorun and Makinde, 1998 ; Perelman, 1999 ; Pennycott and Patterson, 2001 ; Sotiraki et al., 2001 ; PouceGordo et al., 2002 ; Iordanidis et al., 2003 and Mushi et al., 2003). 
Total protein is a useful indicator of the health status with levels lower than $0.39 / \mathrm{L}$ probably suggesting hypoproteinaemia and hypoalbuminaemia which may occur in chronic disease, stomach impaction, malabsorption, chronic and severe parasitism or hepatic diseases (Lewandowsky et al., 1986 and Hochleithner, 1994). Also, changes in metabolites or electrolytes in serum may act as indicator of severe parasitism or endotoxaemia (Mushi et al., 1990).

Barton and Seward (1993) revealed that the Libyostrongylus douglassi are small, blood-feeding nematodes which occlude the ducts of the proventricular glands and this causes a compensatory production of thick mucous which impairs digestion and may lead to impaction. Also Libyostrongylus dentatus has been found in the proventriculus and gizzard of Ostriches (Hoberg et al.,1993 and Landman and Bronneberg,2001).

Ascaridia spp. was found in the small intestine of a rhea species, identification was speculative because the helminth was an immature specimen but it was believed to be Ascaridia orthocerca which is the only Ascaridia spp. that has been seen in ratites (Thomas and Simon, 1996).

Mushi et al. (1998) mentioned that the egg production is decreased when adult Ostrich infect with coccidiosis.

Cryptosporidium species has been shown to infect the bursa, the rectum and the pancreas of Ostrich chicks, which lead to severe losses (Allwright and Wessels, 1993 ; Berzuidenhant et al., 1993 ; Penrith et al. and 1993 Jardine and Verwoerd, 1997).

Heguer (1934) stated that Balantidium spp. is a ciliate and a normal inhabitant of Ostrich intestine, probably capable of becoming somewhat pathogenic under favourable conditions.

The flagellate Histomonas meleagridis is a parasite of turkeys and causes inflammation of caeca and liver and can infect Ostriches in close contact withsuch birds (Borst and Lambers, 1985). 
Trichomonas infection can be acquired by Ostriches via contact with pigeons and doves, it causes pseudo membraneous lesions in the upper digestive tract (Massi et al., 1995 ; Nakamura et al., 2003).

The aim of the present work was an attempt to investigate the prevalence and descriptions of the helminthes and protozoa parasites infestation and its effect in some biochemical parameters in serum of Ostrich.

\section{MATERIAL AND METHODS}

\section{Ostrich samples:}

A total number of 75 Ostrich of various breeds, sexes and ages were used in this study supplied to Animal Health Research Institute for routine examination from El-Beheira and El-Sharkia provinces.

\section{Parasitological examination:}

Each bird was dissected separately. The alimentary tract, viscera and body cavity were opened, washed with physiological saline and sedimented,the sedimented was examined by dissecting microscope for collection of helminthes.the horny layer of gizzard was removed and examined for any embedded parasites. The collected parasites were washed with physiological saline and helminthes were mounted according to Beaver et al. (1984) and identified according to Wordle and Mcleod (1952) ; Yamaguti (1961, 1963, 1971); El-Naffar Kahlifa(1975);Mahdy (1991) and Ahmed (1994).

\section{Faecal examination:}

Ostrich faecal can be examined using focal floatation in sugar salt solution specific gravity 1.2 in sufficient to identify the category of worm present. Simple precipitation or centrifugal flotation should be used with sugar due to viscosity of the solution for the presence of cysts or eggs. 


\section{Microscopical examination:}

For microscopical examination, mucosal scraping were obtained from the surface epithelium of duodenum, jejunum. ileum and cecum of infected Ostrich. Each sample was mixed thoroughly in a few drops of saline and suspended on glass slides to form transparent layer and left at room temperature before staining procedure and stained with Modified Ziehl Neelsen technique (Henorksenand and Pholenz,1981) to examine under oil immersion lens to see the cryptosporidium oocyst.

\section{Biochemical examination :}

Blood samples were collected from each Ostrich via jugular vein punctures and centrifugation occur to separate serum and used for measuring serum total protein (Peters, 1968), serum albumin (Drupt, 1974) and serum globulins were calculated as the difference between total proteins and albumin.

Serum glucose was determined after Trinder (1969), serum cholesterol determined according to Watson (1960), serum calcium was determined according to Gindler and King (1972), serum inorganic phosphorus (Goldenberg, 1966) and serum sodium and potassium (Henry, 1974).

\section{Statistical analysis :}

Student's t-test was used to determine the statistical significance of the results according to Snedecor and Cochran (1982).

\section{RESULTS}

Our present study was design the prevalence and description of parasites infesting Ostrich and its effect in some biochemical parameters in serum. Table (1) revealed that the total infestation rate was75\%.Ascaridia were the most prevalent parasite $25.3 \%$, followed by Libostrongliodies $17.3 \%$. Among the protozoa, Giardia spp.was the most rate of infestation $14.6 \%$. The lowest Blantidim coli $8 \%$ while the Cryptosporidia $13.3 \%$, Trichomonas spp. $9.3 \%$ and Coccidia spp. $12 \%$. 
Table (1): Infestation rate and prevalence of different types of helminthes and protozoa among examined Ostrich.

\begin{tabular}{|c|c|c|c|c|c|c|c|}
\hline \multirow[b]{2}{*}{$\begin{array}{l}\text { No. of examined } \\
\text { Ostrich }\end{array}$} & \multicolumn{2}{|c|}{ Helminthes } & \multicolumn{5}{|c|}{ Protozoa } \\
\hline & 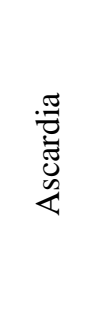 & 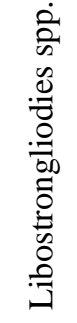 & 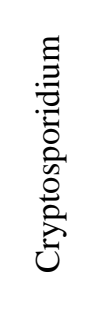 & 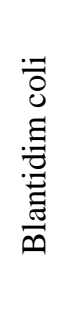 & 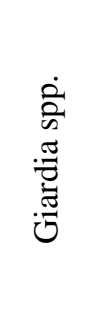 & 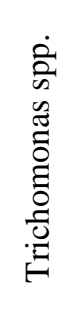 & 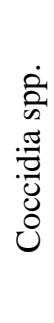 \\
\hline 10 & 5 & - & 3 & - & 0 & 1 & 1 \\
\hline 11 & - & 3 & 2 & - & 2 & 3 & 1 \\
\hline 9 & 4 & 2 & 1 & - & 2 & - & - \\
\hline 5 & 3 & - & 1 & - & - & - & - \\
\hline 15 & 1 & 4 & - & 2 & 3 & 2 & 3 \\
\hline 8 & - & 2 & 1 & - & 2 & - & 4 \\
\hline 12 & 5 & - & 2 & 2 & 2 & - & - \\
\hline 5 & 1 & 2 & - & 1 & - & 1 & - \\
\hline 75 & 19 & 13 & 10 & 6 & 11 & 7 & 9 \\
\hline$\%$ & 25.3 & 17.3 & 13.3 & 8 & 14.6 & 9.3 & 12 \\
\hline
\end{tabular}

\section{Morphology :}

\section{Nematodes :}

Ascaridia worms were found in the small intestine of Ostrich macro examination and microscopic revealed that male Ascardia measured 3040mm long X1-2 mm width with transverse cutical striation.Oral opening is surrounded by three similar sized lips, with dorsal lip having a divided pulp and two papillae (Fig.1). The caudal alae are poorly developed however there is an oval preanal sucker with achitinous ring and 12 pair of caudal papillae. The female measured from 33.8-38.9 (mean 35 X 1.05 $\mathrm{mm}$ ). The nerve ring occurred at $0.19-37 \mathrm{~mm}$ from anterior tip (Fig. 2). 
Libyostrongylus douglassii, is the most deleterious helminth of young Ostrich with mortality rates occasionally. This worm are small, blood feeding nematodes which inhabit and physically occlude the ducts of the proventricular glands. Examination of the fresh proventriculus by stripping the mucosa lining will yield delicate long red worm with a very small buccal cavity (Fig. 3). The male are measured $5.1 \mathrm{~mm}$ long, bursate ray cleft in their distal half forming three branches on each side, and spicules of $0.14-0.16 \mu \mathrm{m}$, each ending in a small large spine (Reineck, 1983).

Libyostrongylus douglassii female measured $4.2 \mathrm{~mm}$ founded in young Ostriches (Fig. 4). The eggs are passed with the faeces of the infected bird. Under optimal conditions of the infective larval stage is reached in 6 hour eggs containing formed embryos can resist desiccation as long as 3 years and the active larvae remain viable under dry conditions for growths or longer. Larvae reach maturity in about 33 days (Solusby, 1982).

Infective larvae $3^{\text {rd }}$ larval stage of L. douglassii are approximately 3 $\mu \mathrm{m}$ long, with 16 triangular cells and $4 \mu \mathrm{m}$ diameter knob typical of stronglids (Fig. 5).

\section{Protozoa :}

Cryptospridiosis:Cryptospridial interitis was recently associated with cases of prolapse of the cloaca in young Ostrich. Cryptosporidia occurred through both the small and large intestine and particularly in the bursa. Cryptosporidial oocysts were found in the faeces of 10 from 75 $(13.3 \%)$ sporulated oocysts showed four elongated sporozoites fulling the oocysts beside a residual oocystic body (Fig. 6) reaching this stage it measured (4- 5 X $4.5 \mu \mathrm{m})$.

Trichomonas : 7 from $75(9.3 \%)$, only trophozoite which has a rapid gliding movement. It's $15 \times 8 \mu$ in size, pyriform, rounded or ovoid in shape (Fig. 6). There are 4 flagella anteriorly and the fifth one turns backward and is attached to the body by an undulating membrane which cover $1 / 3$ to $1 / 2$ the body surface, it has no free part. Undulating membrane is supported at its base by a stiff rod known as the costa. 
Single nucleus with central karyosome. Axostyle forms a thick medium rod and projects posteriorly as a short wedge. Thick para basal body (Fig. 7). A cytostome lies opposite the undulating membrane

Balantidium coli (Trophozoite and cyst) : in caeca and colon

Trophozoite (Fig. 8): It's $45 \times 60 \mu$ in size, oval in shape with a conical anteriorly and abroad posteriorly. Periplast is covered by cilia, which are thicker and longer anteriorly around the mouth opening or cytostome. These cilia help to direct food towards the cytostome, which leads to a cytopharynx that extends to $1 / 3$ of body length. There is an anal pore or cytopyge at the posterior end through which waste products from contractile vacuoles are emptied. Cytoplasm is dedifferentiated into a clear ectoplasm and granular endoplasm which contains many food vacuoles, contractile vacuoles and 2 nuclei, a large kidney-shaped macronucleus concerned with vegetative functions and a smaller rounded micronucleus concerned with generative functions.

Balantidium coli cyst (isolated from colon) : 40-60 $\mu$, broadly oval is shape with thick double wall containing single organism with vacuoles and a macronucleus and micronucleus (Fig. 8).

Giardia lambilia : isolated from small intestine

Trophozoite: $15 \times 8 \mu$ in size, pear shaped or oval, bilaterally symmetrical with dorsal surface is convex as half appear in lateral view, 2 depressed sucking discs supported by 2 fibrils are present anteriorly on the ventral surface, each suckling disc contains a vesicular nucleus with central karyosome. There are 4 pairs of flagella, $1^{\text {st }}$ pair arise anteriorly in middle line, $2^{\text {nd }}$ pair arise between 2 discs and become free laterally, $3^{\text {rd }}$ pair arise laterally behind the disc and becomes free posteriorly. A comma shaped para basal body crosses the axostyle, it may be paired (Fig. 9).

Cysts : are found in small intestine. It's about 12 X $8 \mu$ with smooth well-developed cyst wall. Cytoplasm is shrunken from the cyst wall. 4 vesicular nuclei are present mostly at one pole. Axostyle is visible as a rod dividing the cyst with para basal body crossing it. Remnants of flagella are cailed in the cytoplasm (Fig. 10). 
Coccidia : found in intestine cecum and colon, faecal samples from 75 adult Ostriches reported 9 (12\%) coccidian spp. Oocysts (Fig. 11) sporulated oocysts measured $4-6.1$ X $3.3-5.0 \mu \mathrm{m}$ and contained four sporozoites.

Table(2)revealed that there is a hypoproteinia and hypoalbumineamia and hypoglobulinaemia. Glucose level in our study lower than the control group and cholesterol show hypocholesterolaemia.Sodium remains within the normal range, calcium level was decreased and phosphorous level within the normal range.

Table (2): Some biochemical changes in serum of Ostrich infested with arasites.

\begin{tabular}{|c|c|c|c|c|c|c|}
\hline & Groups & Means & $\overline{\text { St. D }}$ & Min. & Max. & T-test \\
\hline $\begin{array}{l}\text { Protein } \\
\text { g/L }\end{array}$ & $\begin{array}{l}\text { Control } \\
\text { Infested }\end{array}$ & $\begin{array}{l}0.387 \\
0.206\end{array}$ & $\begin{array}{l}0.018 \\
0.018\end{array}$ & $\begin{array}{l}0.036 \\
0.170\end{array}$ & $\begin{array}{l}0.410 \\
0.230\end{array}$ & $9.587 * * *$ \\
\hline $\begin{array}{l}\text { Albumin } \\
\mathrm{g} / \mathrm{L}\end{array}$ & $\begin{array}{l}\text { Control } \\
\text { Infested }\end{array}$ & $\begin{array}{l}0.155 \\
0.087\end{array}$ & $\begin{array}{l}0.0045 \\
0.0061\end{array}$ & $\begin{array}{c}0.147 \\
0.08\end{array}$ & $\begin{array}{l}0.160 \\
0.095\end{array}$ & $10.628 * * *$ \\
\hline $\begin{array}{l}\text { Globulin } \\
\mathrm{g} / \mathrm{L}\end{array}$ & $\begin{array}{l}\text { Control } \\
\text { Infested }\end{array}$ & $\begin{array}{l}0.230 \\
0.145 \\
\end{array}$ & $\begin{array}{l}0.004 \\
0.002 \\
\end{array}$ & $\begin{array}{l}0.224 \\
0.142 \\
\end{array}$ & $\begin{array}{l}0.237 \\
0.148 \\
\end{array}$ & $40.522 * * *$ \\
\hline $\begin{array}{l}\text { Glucose } \\
\mathrm{Mg} / \mathrm{L}\end{array}$ & $\begin{array}{l}\text { Control } \\
\text { Infested }\end{array}$ & $\begin{array}{l}25.11 \\
19.36\end{array}$ & $\begin{array}{l}0.809 \\
0.807\end{array}$ & $\begin{array}{l}23.7 \\
17.9\end{array}$ & $\begin{array}{l}26.2 \\
20.2\end{array}$ & $6.793 * * *$ \\
\hline \begin{tabular}{|c|}
$\begin{array}{c}\text { Cholesterol } \\
\mathrm{Mg} / \mathrm{L}\end{array}$ \\
\end{tabular} & $\begin{array}{l}\text { Control } \\
\text { Infested }\end{array}$ & $\begin{array}{l}9.54 \\
7.41 \\
\end{array}$ & $\begin{array}{l}0.481 \\
0.678 \\
\end{array}$ & $\begin{array}{l}8.7 \\
6.5 \\
\end{array}$ & $\begin{array}{c}10.1 \\
8.5 \\
\end{array}$ & $2.991 *$ \\
\hline $\begin{array}{l}\text { Sodium } \\
\mathrm{m} \text { mol./L }\end{array}$ & $\begin{array}{l}\text { Control } \\
\text { Infested }\end{array}$ & $\begin{array}{l}146.92 \\
143.64 \\
\end{array}$ & $\begin{array}{l}3.815 \\
3.113 \\
\end{array}$ & $\begin{array}{l}139.9 \\
139.7 \\
\end{array}$ & $\begin{array}{l}152.1 \\
148.2 \\
\end{array}$ & $1.0046 \mathrm{n} . \mathrm{s}$ \\
\hline $\begin{array}{l}\text { Calcium } \\
\mathrm{m} \text { mol./L }\end{array}$ & $\begin{array}{l}\text { Control } \\
\text { Infested }\end{array}$ & $\begin{array}{l}2.53 \\
1.79\end{array}$ & $\begin{array}{c}0.2311 \\
0.137\end{array}$ & $\begin{array}{l}2.1 \\
1.6\end{array}$ & $\begin{array}{l}2.8 \\
2.0\end{array}$ & $5.150 * * *$ \\
\hline \begin{tabular}{|c|} 
Phosphorus \\
m mol./L \\
\end{tabular} & $\begin{array}{l}\text { Control } \\
\text { Infested }\end{array}$ & $\begin{array}{l}1.95 \\
1.91 \\
\end{array}$ & $\begin{array}{l}0.1080 \\
0.1197 \\
\end{array}$ & $\begin{array}{l}1.8 \\
1.7 \\
\end{array}$ & $\begin{array}{l}2.1 \\
2.1 \\
\end{array}$ & 0.318 n.s \\
\hline
\end{tabular}

\section{DISCUSSION}

The present study revealed that the infestation rate of helminth parasites, among examined Ostriches in Table (1) were $25 \%$ Ascaridia and these results were lower than that recorded by Reinecke (1983) (12.3 $\%)$. The difference in this infestation rate in these work may be due to the different of its localities. 
Libostrongyloides was $17.3 \%$, this agree with Barton and Swward (1993). The protozoa like Giardia infestation was $14.6 \%$, Blantidium coli was $8 \%$ and this agree with Heguer (1934) while Cryptosporidium was $13.3 \%$ and this agree with Gajadhar (1993) and Penrith (1993). The Tichomonas spp. was $9.3 \%$ and this agree also with Pentrith (1993) in percent and description.

The coccidia was $12 \%$ in this study, there have been several reports of coccidia in ratites however without inflammation regarding size, shape, sporulation or other morphologic criteria for speciation on examination of the intestines of the birds, our results evident to the description of Soulsby (1982).

Table(2)revealed that there is a hypoproteinia and hypoalbumineamia and hypoglobulinaemia,this changes may occur due to dehydration or during infestation which cause a stimulation of immune system increasing in levels of immunoglobulin (Hochleithner, 1994).

Glucose level in our study lower than the control group and this result indicate hypoglycaemia which may be occur due to stress, starvation or severe parasitism (Fudge, 1996).

Also,cholesterol in Table(2) show hypocholesterolaemia this may be related to endotoxaemia (Hachleithner, 1994).

The level of sodium in Table (2) show sodium remains within the normal range.Gray et al.(1988) revealed that electrolytes are quite stable in Ostrich even during dehydration.

Table (2) revealed that calcium level were decrease, this may be due to its bound to serum protein (hypoproteinaemia) and this result agree with Change et al. (1988) and Brown and Jones (1996).

Phosphorous level within the normal range, changes in phosphorous concentrations may occur during different disease but not on consistent basis (Brown and Jones, 1996). 


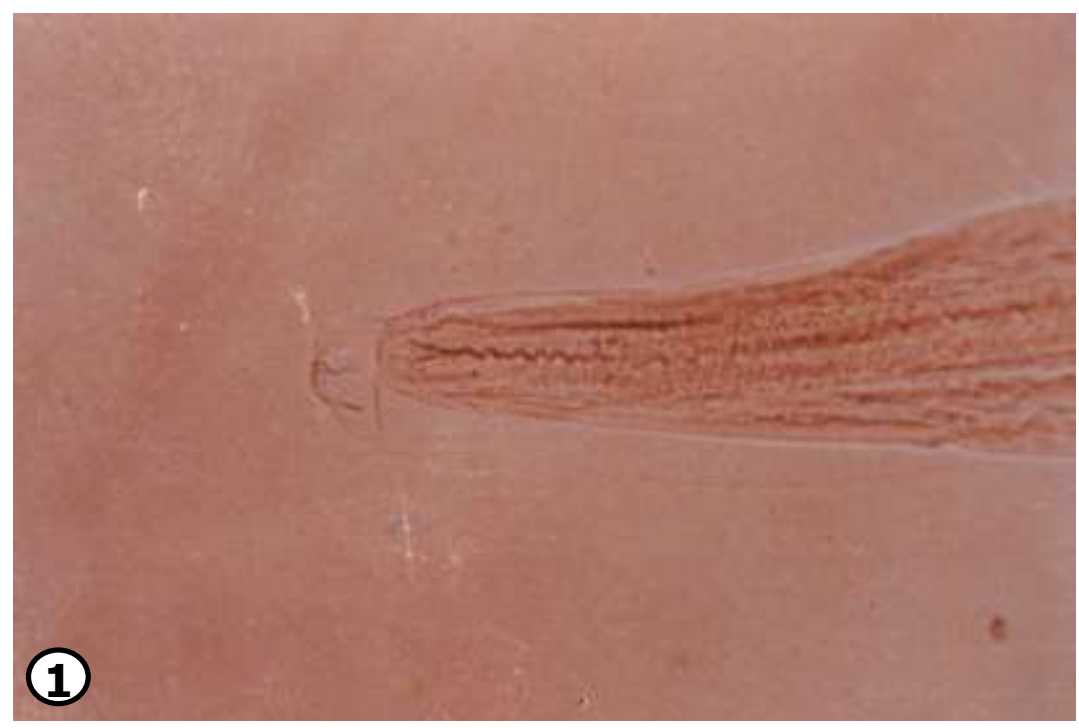

Fig (1): Ascaridia orthocerca anterior end from small intestine X 250.

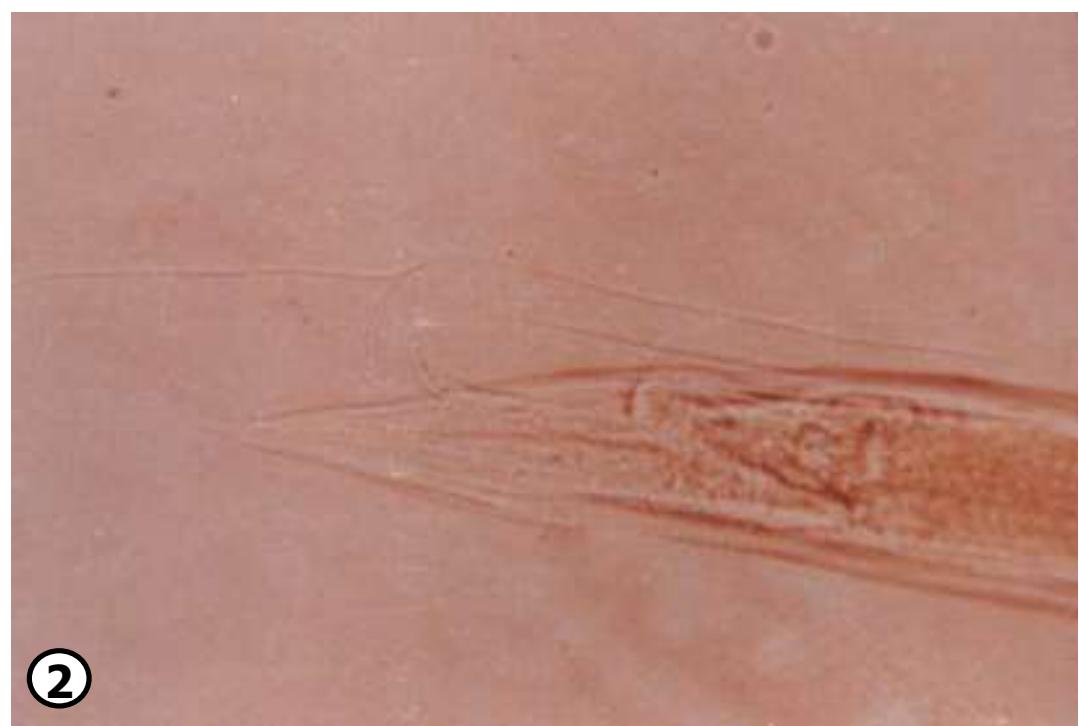

Fig (2): Ascaridia orthocerca female posterior end X 250.

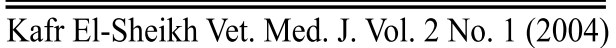




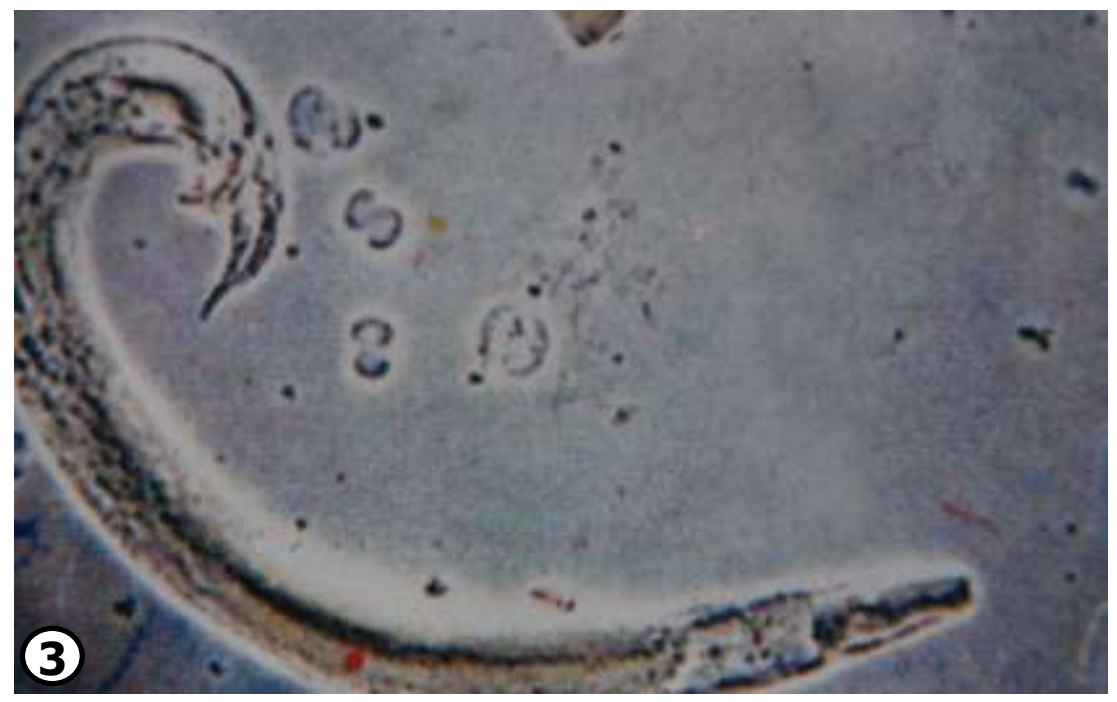

Fig (3): Libostrongyloides male X 1000.

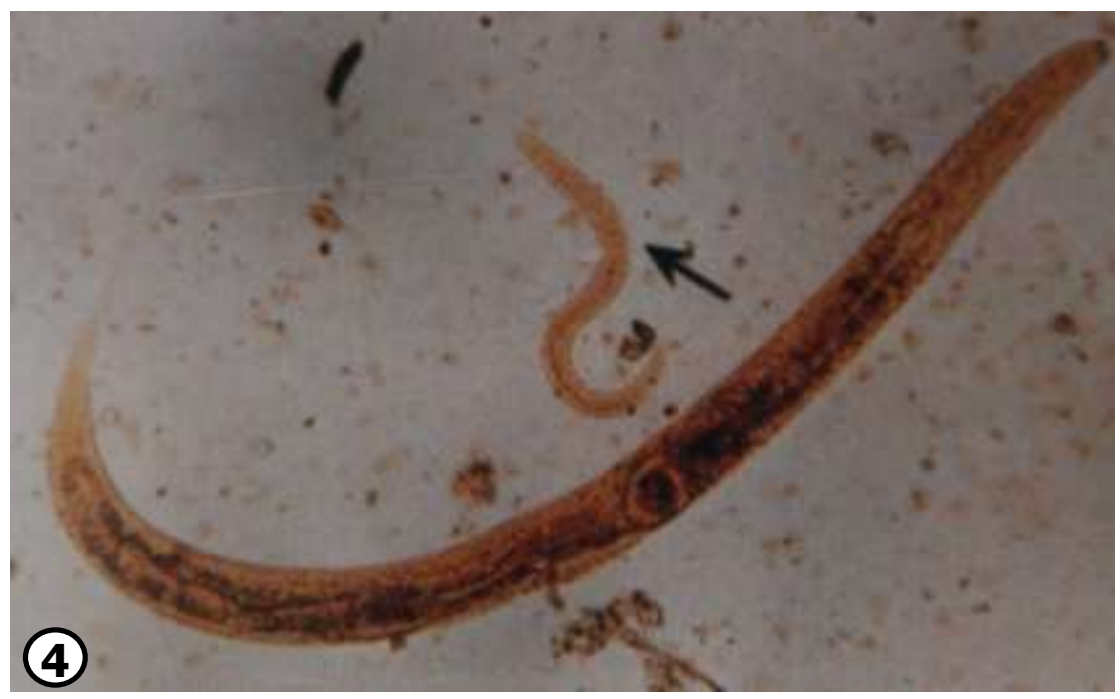

Fig (4): Libostrongyloides female X100.

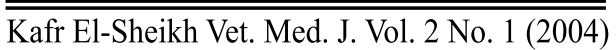




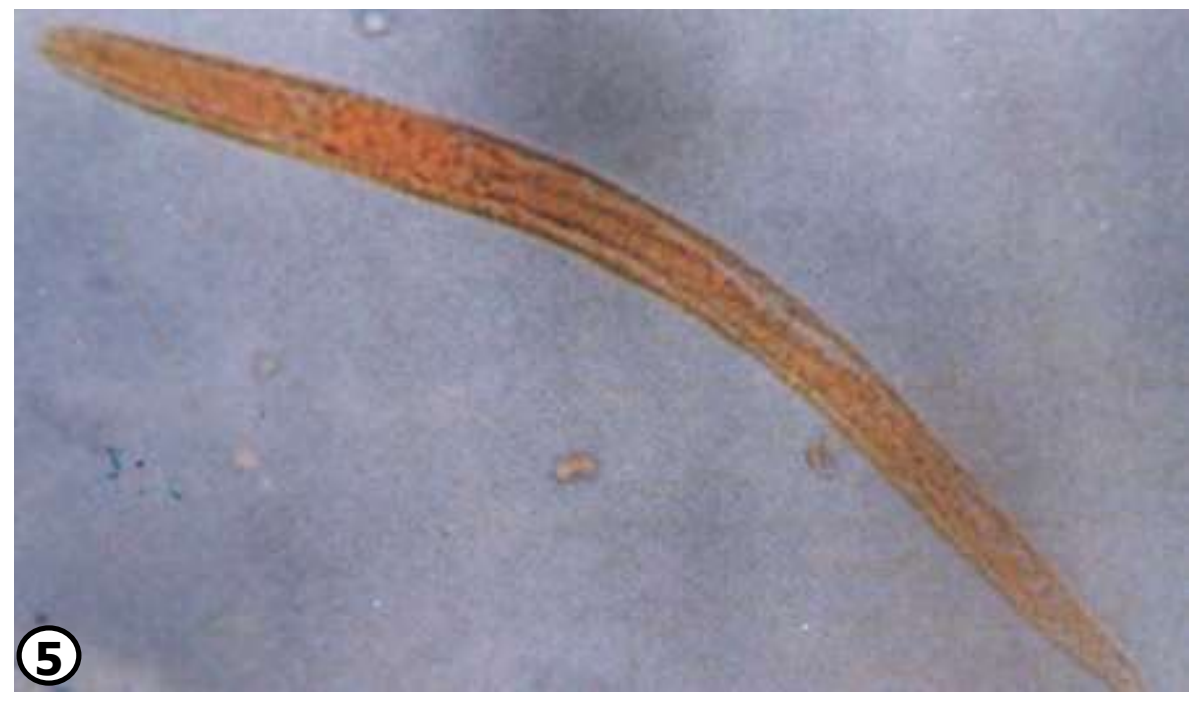

Fig (5): Libostrongyloides larvae X 1000.

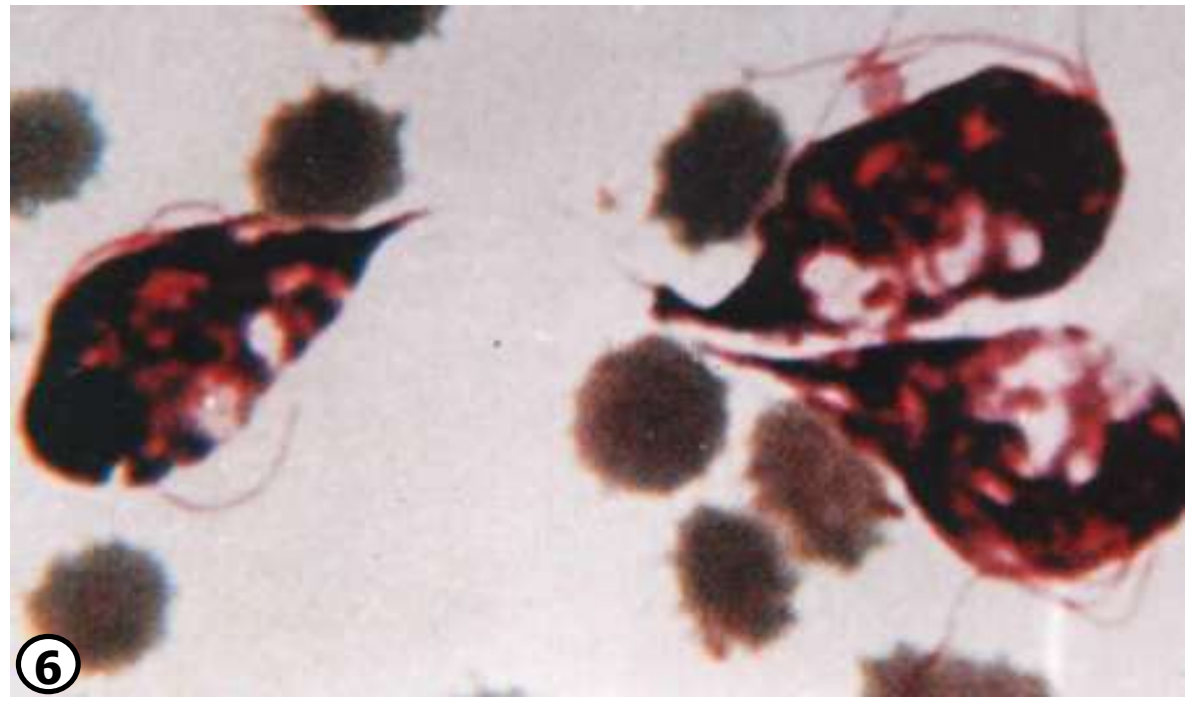

Fig (6): Cryptosporidium X 1333.

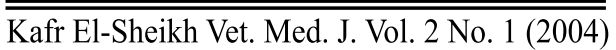




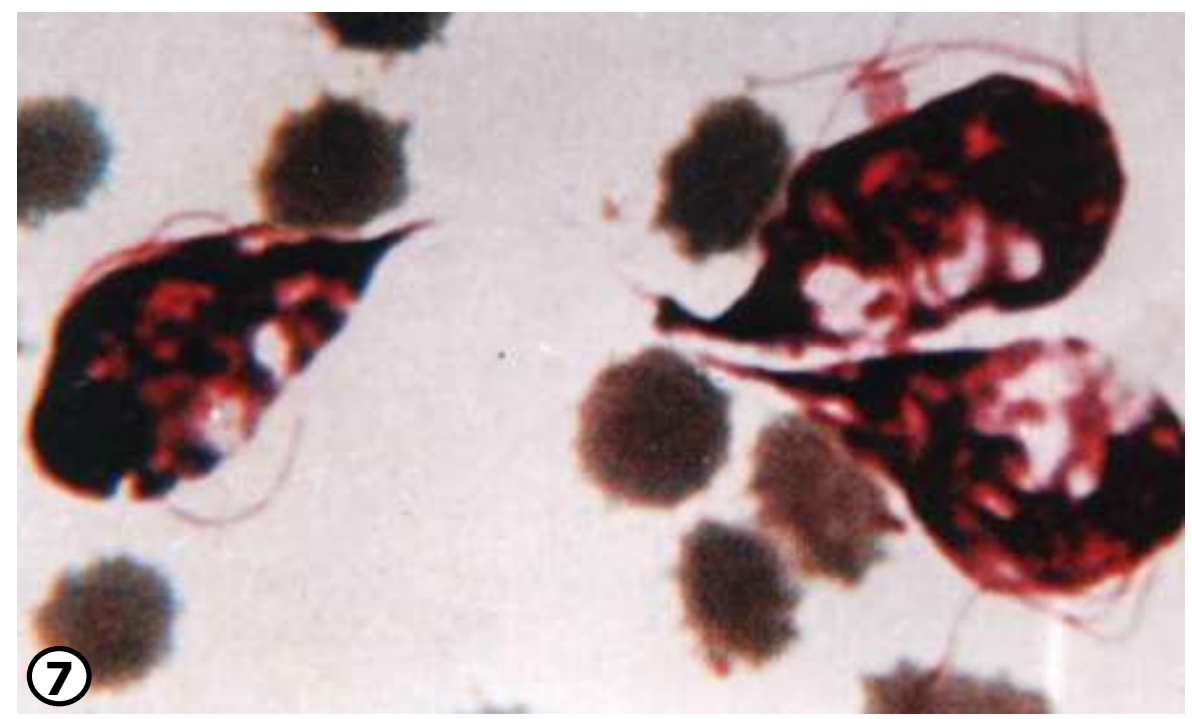

Fig (7): Trichomonas meleagridis X 1000.

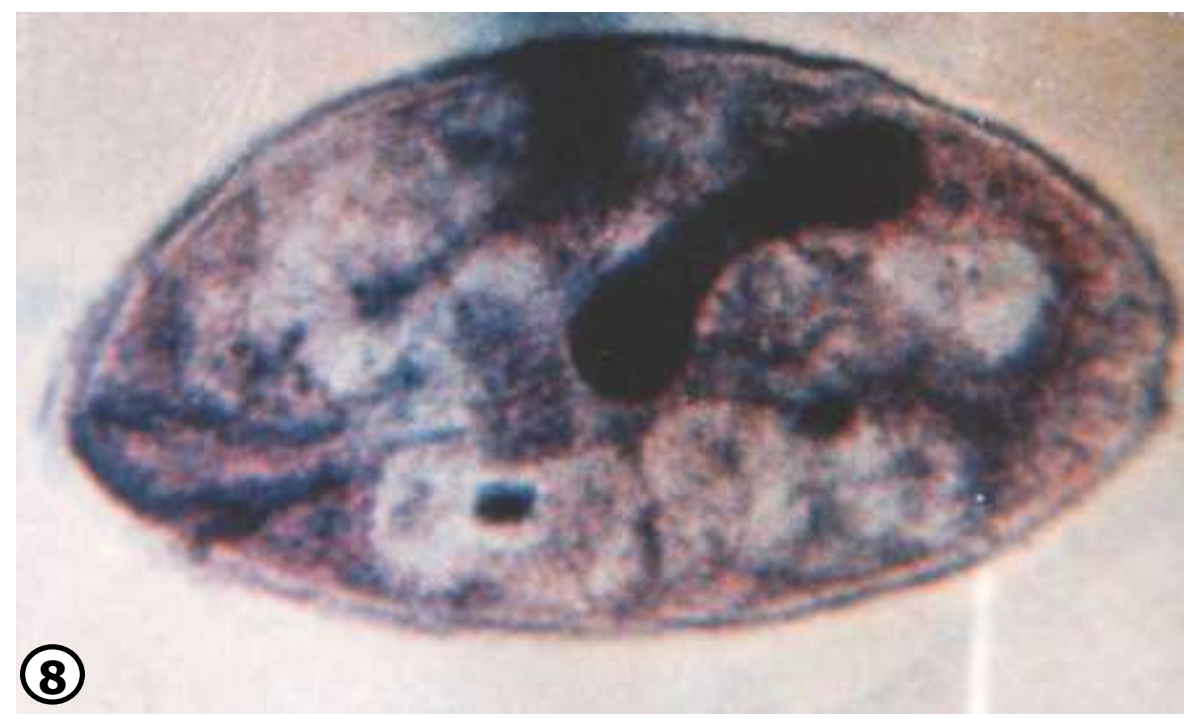

Fig (8): Blantidium coli trophozoite X 1000.

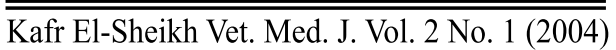




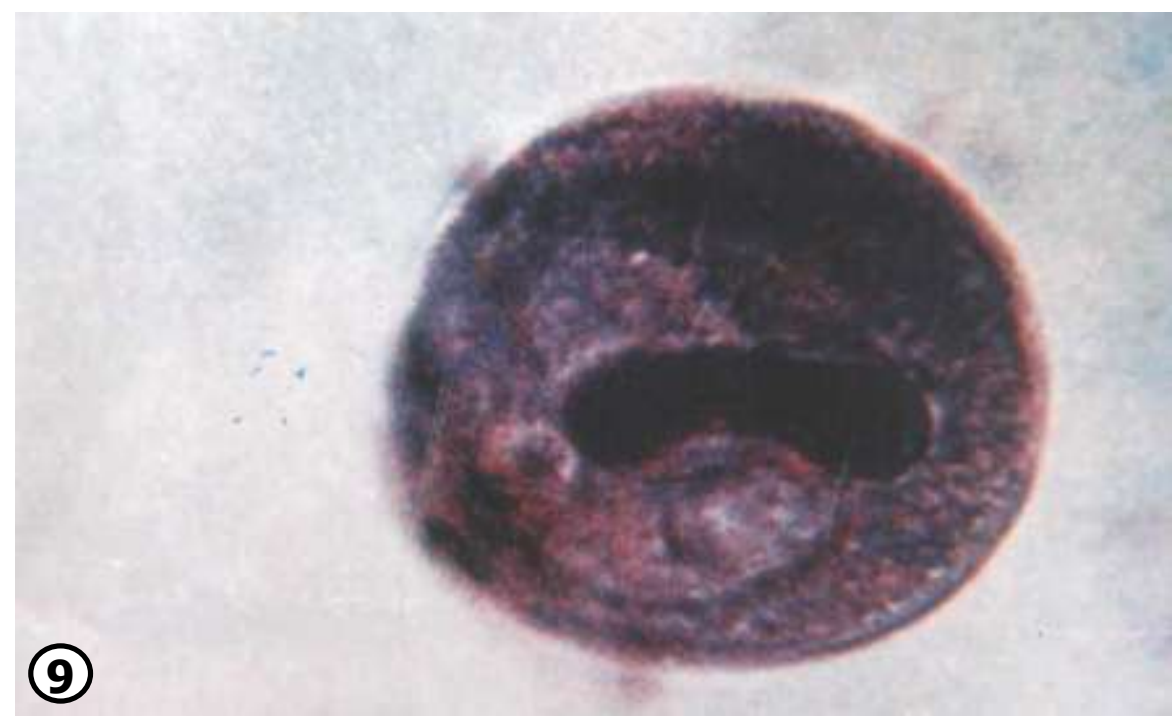

Fig (9): Blantidium coli cyst X 1000.

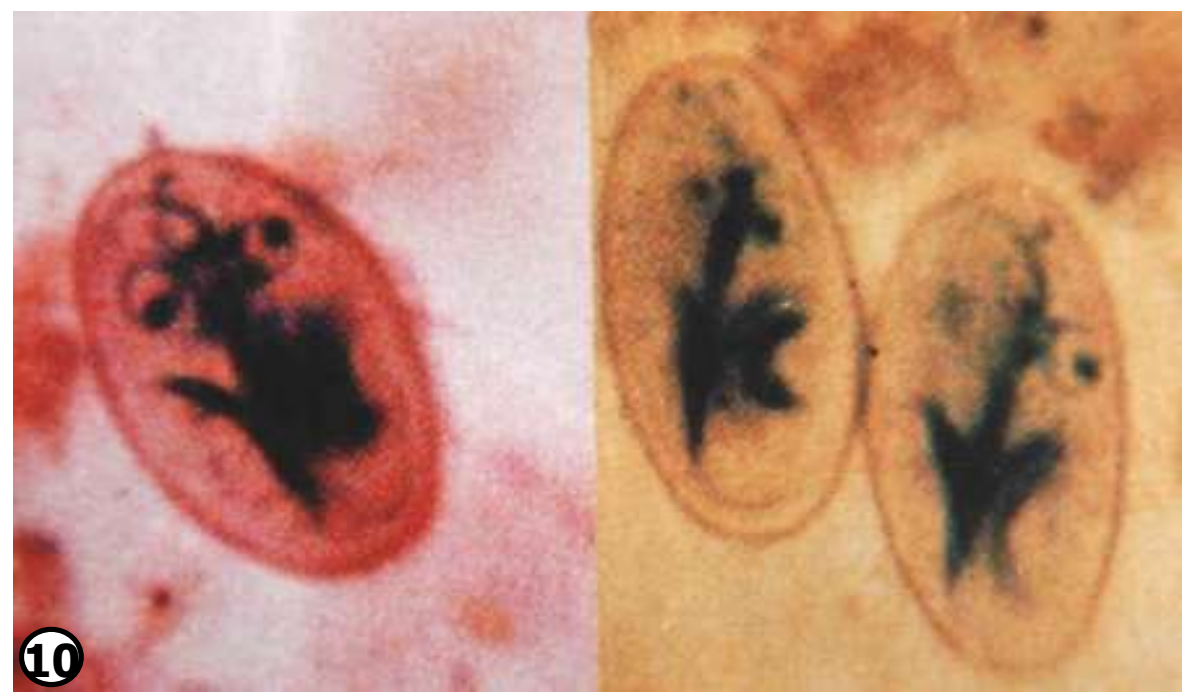

Fig (10): Giardia cysts X 400.

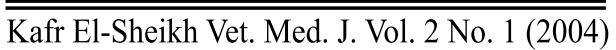




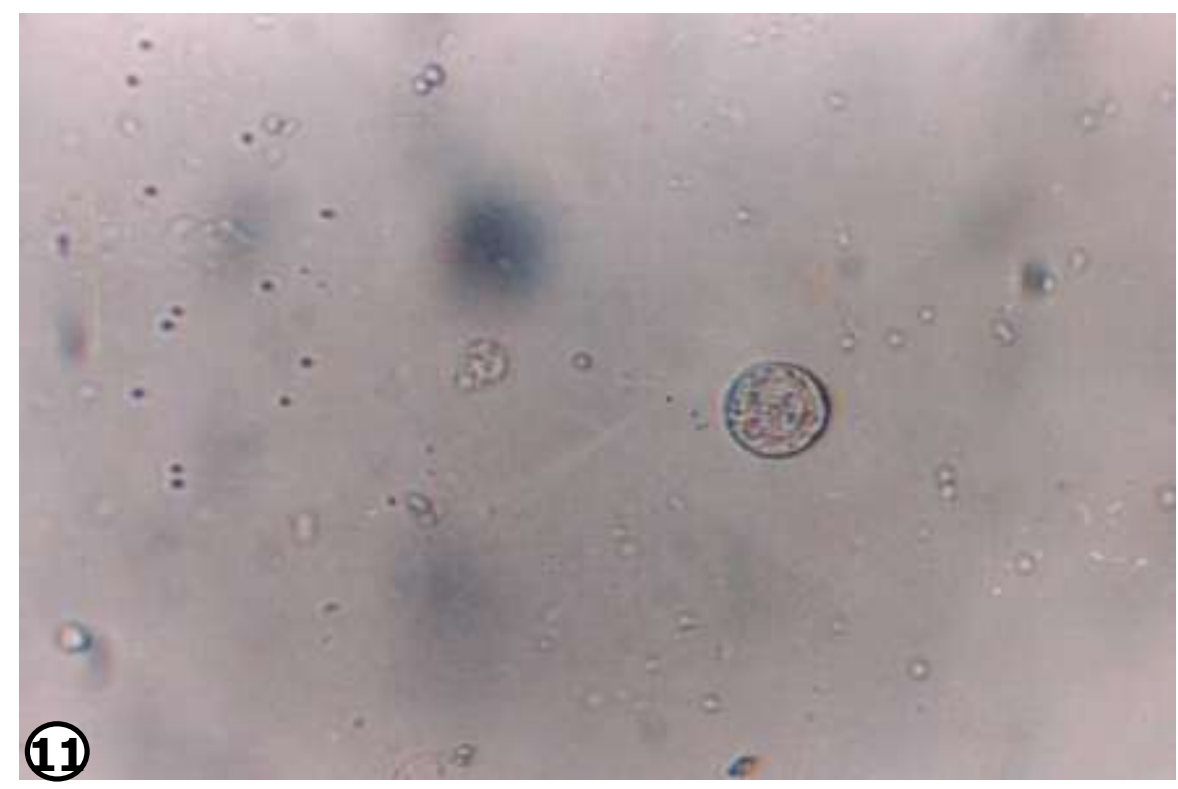

Fig (11): Coccidia oocysts X 400.

\section{REFERENCES}

- Ahmed, N. M. (1994): Helminth parasites of some wild birds. M. V. SC. Thesis (Parasitology), Fac. Vet. Med. Zagazig Univ.

- Allwright, D. M. and Wessels, J. (1993): Cryptosporidium species in Ostriches.Vet. Rec., $133: 24$.

- Batron, N. J. and Seward, D. A. (1993): Detection of Libyostrongylus douglassi in Ostriches in Australia. Aust. Vet. J., 70 : 31 - 32.

- Beaver, K. C. ; Jun, R. C. and Cupp, E. W. (1984): Clinical Parasitology, USA Lea Febiger, Philadelphia.

- Berzuidenhant,A. J.and Burgen,W.P.(1993): The incidence of Tibiotarsal rotation in the Ostrich (Strathio camelus). J. South African Vet. Assoc., $64: 159$ - 161.

- Borst,G. H.A.and Lambers, G. M. (1985): Typhlohepatitis bij struisvogels (Struthio camelus) veroorzaakt door een histomiasis infection. Tijdschidt Voor Diergeneeskunde, 110 : 536.

Kafr El-Sheikh Vet. Med. J. Vol. 2 No. 1 (2004) 
- Brown, C. R. and Jones, G. G. E. (1996): Some blood chemical electrolyte and mineral values of some young Ostriches. J. South African Vet. Assoc., 67 : 111 - 114.

- Change, P. H. ; Chang, C. F. ; Luil, M. R. and Wang, K. P. (1988): Bow leg syndrome in Ostrich (Struthio camelus) J. Chinese Society Vet. Sci.,14 : 17 - 21 .

- Deeming, D. C. (1999) : The Ostrich Biology, Production and Health. British Library, London, UK. PP, 293 - 319.

- Drupt, F.(1974): Colorimetric method for determination of albumin. Pharm. Bio., $9: 777$.

- El-Naffar, M. and Khalifa, R. (1975): Parasite journal of the Egyptian aquatic birds. Trematode Parasites of the buff. Bucked herou (Ardeola ibis) in Assuit Governorate, Egypt. J. Egypt. Soc. Parasit., 485 : 42 - 56.

- Fudge,A. M.(1996): Clinical hematology and chemistry of ratities.In: Tully, T. N. and Shane, S. M. (eds.) Ratite Management Medicine and Surgery. Krieger Publishing Malabar, Florida, PP. 105 - 114.

- Gajadhar,A. A. (1993): Cryptosporidium species in imported Ostriches and consideration of possible implications for birds in Canada. Can. Vet. J., 34 : 115 - 116.

- Gajadhar, A. A. (1994) : Host specificity studies and oocyst description of a cryptospiridun species isolated from Ostriches Parasitol Res., 80 : 316-319.

- Gindler, E. M. and King, J. D. (1972) : Rapid colorimetric determination of calcium in biological fluids with methylthynol blue. Am. J. Clin. Path., 58: 376.

- Goldenberg,H. (1966): Colorimetric method for determination of inorganic phosphorus. Clin. Chem., $12: 871$.

- Gray,D. A.; Naude,R.I.and Erasmus, I. (1988) : Plasma arginine vastocin and angiotensin in the water deprived Ostrich (Struthio camelus). Comp. Biochem. Phsiol., 89 A : 251 - 256. 
- Heguer, R. (1934): Specificity of the genus Balantidium based on size and shape of body and macronucleus, with description of six new species. Am. J. Hyg., 19 : 38 - 67.

- Henery, R.F. (1974): Colorimetric method for determination of sodium and potassium in serum and plasma.Clinical chemistry Principles and Technics., $2^{\text {nd }}$ Ed., Harper and Ron.

- Henriksen, S. A. and Pohlenz, J. F. L. (1981): Staining of cryptosporidium by a modified Ziehl Neelsen Technique Act. Vet. Second., 22 : 594 - 596.

- Hoberg, E. P. ; Lioyd, S. and Omar, H. ; (1993): Libyostrougylus dentalus n.sp. (Nematoda: Trichostrongyloidae) from Ostrich in North America with comments on the genera Libyostrongylus and Paraslibyostrongylus. J. Parasitol., 81 : 85 - 93.

- Hochleithner, M. (1994): Biochemistrities in: Ritchine, B.W.;Harrison, G.J. and Harrison, L.R.(eds).Avian medicine:Principles and Application. Wingers Publishing, Lake Worth, Florida, P.P. 223 - 242.

- Iordanidis,P.I.;Papazahariadou,M. G. ; Georgiades, G. K.; Papaiannou, N. G. and Frydas, S. E. (2003): Cloacal Prolapse in Ostrich chicks with histomoniasis. Vet. Rec., 4; 153 (14) : 434-435.

- Jardine, J. E. and Verwoerd, D. J. (1997) : Pancreatic cryptosporidiasis in Ostriches. Avian Pathol., 26 : 665 - 670.

- Landman,W. J.and Bronneberg,R. G. (2001): Libyostrongylus douglassii in Ostriches(Struthio camelus sp.)in the Netherlands. Tijdschr Diergeneeskd, 1; 126 (14-15) : 484 - 487.

- Levy, A.;Perelman,B.;Waner, T.;Van Grevenbroek, M.;VanGrevekl,C. and Yagil, R. (1989) : Haematological Parameters of the Ostrich (Struthio camelus). Avian Pathol., 18 : 321 -327.

- Lewandowsky,A.H.;Campbell,T.W.and Harrison, G. J. (1986): Clinical chemistries. In : Harrison, G.J. and Harrison, L.R. (eds). Clinical Avian medicine and surgery. W.B. Saunders, Philadelphia, P.P. 192-200.

- Mahdy, Olfat, A. (1991): Morpho-Biological studies on the role of some fresh water fishes in transmitting parasitic helminthes of some avian hosts. Ph. D. Thesis (Parasitology). Fac. Vet. Med. Cairo Univ.

Kafr El-Sheikh Vet. Med. J. Vol. 2 No. 1 (2004) 
- Massi,P.;Dottorini,M.;Pavesi,M. and Silimbani, E. (1995) :

Osservazioni sulla pathologia dello struzzo(Struthio camelus)e prime indogini di laboratorio di Forli. Zootechnia International, February, 76 77.

- Mushi, E. Z. ; Binta, M. G. ; Chabo, R. G. and Toto, P. A. (2003) : A note on endoparasites of wild Ostriches (Struthio camelus) in the Mokolodi Nature Reserve, Gaborone, Botswana. J. S. Adr. Vet. Assoc., 74 (1): 22 - 23.

- Mushi, E. Z. ; Isa, J. F. ; Chabo, R. G. ; Binta, M. G. ; Kapaata, R. W. ; Ndebele,R. T. and Chakalisa, K. C. (1998): Coccidia qqcysts in the faeces of farmed Ostrich(struthio camelus) chicks in Botswana. Onderstepoort J.Vet. Res. (1998), Dec; 65 (4) : 281-284.

- Mushi,E. Z. ; Isa, J.F. W. ; Chabo, R. G. ; Binta, M. G. ; Modisa, L. and Kamau,J.M.(1998):Impaction of the stomachs in farmed Ostriches (Struthio camelus) in Botswana. Avian Dis., 42 : 597-599.

- Nakamura, T. ; Miura, T. ; Nakaoka, T. ; Nagano, J. Takahashi, Y. and Guamoto, A. (2003) : A case of trichinellosis with Spontaneous remission. Kansenshogaleu Zasshi., 77 (10) : 839-843.

- Okotie-Eboh, G. ; Bailey, C. A. ; Hicks, K. D. and Kubena, L. F. (1992): Reference serum biochemical values for emus and Ostriches.Am.J.Vet. Res., 53: 1765- 1768.

- Olowookonum,M.O. and Makinde,M.O.(1998): A comparative assessment of erythrocyte osmotic fragility, haematological and serum biochemical values in the domestic chicken and the Ostrich. In: Huchzermeyer, F.W.(ed) Ratite Congress, Oudtshoorn, South Africa, PP. 99 - 101.

- Pennycott,T.and Patterson,T.(2001): Gastrointestinal parasites in Ostriches (Struthio camelus) Vet. Rec., 3 ; 148 (5) : 155 - 156.

- Penrith,M.L.;Burger,W.P.(1993): Acryptosporidin in an Ostrich J. African Vet. Assoc., 64 : 60 - 61.

- Perelman, B. (1999): Health management and veterinary procedures. The Ostrich: Biology production and Health (ed.), 321- 347. 
- Peters,T.(1968): Colorimetric method for determination of total serum proteins. Clin. Chem., 14 : 1147.

- Peuridth, M. L. ; Bezuidenhout, A. J. ; Burger, W. P. and Putterill, J. $F$. (1994) : Evidence for cryptosporidial infection as a cause of prolapse of the phallus and cloaca in Ostrich chicks (Struthio camelus). Onderstepoort J. Vet. Res., 61 : 283 - 289.

- Ponce-Gordo, F. ; Herrera, S. ; Gastro, A. T. ; Garcia Durau, B. and Martinez Diaz, R. A. (2002) : Parasites from farmed Ostriches (Struthio camelus) and rheas (Rhea americana) in Europe. Vet. Parasitol.,29,107 (1-2): $137-160$.

- Reinecke, R. K. (1983) : Veterinary helminthology. Durban Il Butterworths Publishers.

- Snedecor, G. W. and Cochran, W. G. (1982) : Statistical Methods. $8^{\text {th }}$ Ed., Ames. Iowa State University.

- Sotiraki, S. T. ; Georgiadas, G.;Antoniadou-Sotiriadou,K.and Himonas, C. A. (2001): Gastrointestinal parasites in Ostriches (Struthio camelus). Vet. Rec., 20; 148 (3) : $84: 86$.

- Soulsby, E.J.L.(1982): Helminthes, arthropods and protozoa of domesticated animals. 7th ed., Philadelphia, Lea and Febiger.

- Thomas, N. T. and Simon, M. S. (1996) : Ratite management medicine and surgery, Krieger Publishing Company, Malabar, Florida, pp. 115 126.

- Trinder,P.(1969): Enzymatic determination of glucose.Ann.Clin. Biochem., $6: 24$ - 26.

- Van Heeden,J.;Dauth,J.;Jarvis,M.J.E.;Keffen,R.H.;Denny,J. E. E. M. ; Dreyer, M. J. and Krier, N. P. J. (1985) : Blood chemical and electrolyte concentration in the Ostrich (Struthio camelus).J.South African.Vet. Assoc., $56: 75$ - 97.

- Wardle,R.A.and Mcleod,J.A.(1952):The zoology of tape worms published for the university of Minnesota press, Minnesota library of Congress Catalog card No. $52: 5321$.

- Watson, D. (1960) : A simple method for detection of serum cholesterol. Clin. Chem. Acta., $5: 637-643$. 
- Yamaguti,S.(1961):Systema helminthum.Vol.III Parts I and II the nematodes of vertebrates. Interscience Publ., New York, pp. 1261.

- Yamaguti, S. (1963): Systema helminthum. Vol. V Acanthocephala Inters-cience Publ., New York, pp. 421.

- Yamaguti, S. (1971): Synopsis of digentic trematodes of vertebrates. Vol. 12 II Keigaku Publishing Co., Tokyo, Japan. 